\title{
Evaluation of Dental Erosion in a Group of Romanian Children Diagnosed with Gastroesophageal Reflux Disease
}

\author{
Krisztina Mártha1', Alexandru Ogodescu², Daniela Eșian³, Cristina Bica³, Eugen Bud¹ \\ 1 Department of Orthodontics, Faculty of Dental Medicine, University of Medicine and Pharmacy, Tîrgu Mureş, Romania \\ 2 Department of Pedodontics, Faculty of Dental Medicine, „Victor Babes” University of Medicine and Pharmacy, Timișoara, Romania \\ 3 Department of Pediatric Dentistry, Faculty of Dental Medicine, University of Medicine and Pharmacy, Tîrgu Mureş, Romania
}

\section{CORRESPONDENCE}

\section{Alexandru Ogodescu}

"Victor Babeș" University of Medicine and Pharmacy, Faculty of Dental

Medicine

Bd. Revoluției din 1989 nr. 9

300070 Timisoara, Romania

Tel: +40723544336

E-mail: ogodescu@yahoo.com

\section{ARTICLE HISTORY}

Received: 3 March, 2017

Accepted: 8 March, 2017
Krisztina Mártha • Str. Gheorghe Marinescu nr 38 540139 Tîrgu Mureș, Romania, Tel: +40 265215551 Daniela Esian • Str. Gheorghe Marinescu nr. 38 540139 Tîrgu Mureș, Romania, Tel: +40 265215551 Cristina Bica • Str. Gheorghe Marinescu nr. 38 , 540139 Tîrgu Mureș, Romania, Tel: +40 265215551 Eugen Bud • Str. Gheorghe Marinescu nr. 38, 540139 Tîrgu Mures, Romania, Tel: +40 26521555

\begin{abstract}
Gastroesophageal reflux disease (GERD) is a very common digestive disorder, which occurs when the acidic contents of the stomach returns into the esophagus to some extent, reaching the mouth, thereby increasing the frequency of dental erosion and caries. Since saliva plays a huge role in oral homeostasis, it is important to examine the role of this parameter in the appearance of the above mentioned oral lesions. The aim of our study was evaluate the oral condition of children suffering from reflux disease and to assess the relationship between salivary $\mathrm{pH}$ and the incidence of dental erosion and caries. In this prospective study we examined 25 children diagnosed with GERD, referred for hospitalization. Bedside intra-oral examination (DMFT index, gingival index) and strip method $\mathrm{pH}$ value determination was performed. We observed that patients with low $\mathrm{pH}$ values had increased caries frequency, and dental erosion was also noticeable. Statistical significance was determined comparing the DMFT index in groups with different $\mathrm{pH}$ values. We concluded that the high number of erosions is closely related to gastroesophageal reflux disease, as a consequence of the low pH value, which represents the main cause of oral manifestations in GERD
\end{abstract}

Keywords: gastroesophageal reflux disease, dental erosion, salivary pH

\section{INTRODUCTION}

Knowing the pathogenesis of gastroesophageal reflux disease (GERD), it has become obvious, that besides its typical signs and symptoms, it can lead to a series of other disorders. Recognizing them will help us choose the right treatment procedure, especially etiological treatment. Besides sleep apnea or other apparent life-threatening events (ALTE), obstructive bronchitis and asthma, recurrent pneumonia and pulmonary fibrosis, laryngitis, laryngomalacia, rhinopharyngitis, chronic sinusitis or otitis media, specific dental problems can also occur as a consequence of GERD.

Tooth wear, the non-carious loss of tooth substance due to certain physical and/or chemical actions, is irreversible and has a chronic evolution. The most 
common type of tooth wear is dental erosion, a chronic, localized and usually painless loss of dental hard tissues due to chemical dissolution by acids of non-bacterial origin. Although its increasing frequency even in countries with advanced prophylaxis and good dental and oral hygiene is evidence-based, minor details of correlation between GERD and dental erosion are still unclear.

The aim of our study was to underline some of these correlations by examining children diagnosed with GERD and to find certain correlations among the disease, the salivary $\mathrm{pH}$ and the variety of dental and gingivo-mucosal lesions that can occur.

\section{MATERIAL AND METHODS}

The subjects of this prospective clinical study were selected from patients referred to the II Children's Hospital of the University of Medicine and Pharmacy of Tîrgu Mureș. The examinations were performed between February - May 2016, and the study was approved by the Ethics Committee of the university. We selected 11 girls and 14 boys. Each patient was referred to pediatric consultation for specific GERD symptoms (retching, abdominal pain, "heartburn" etc.), and the diagnosis was based on endoscopic examination. Most commonly, the patients were following a pro-kinetic treatment to increase the lower esophageal sphincter pressure and improve gastric peristalsis. ${ }^{1}$

The patients' or their legal tutor's written consent was obtained in every case. Salivary pH directly from the oral cavity, caries index, gingival index and dental status were determined for every patient.

Dental and gingival status examination was carried out bedside, the caries and gingival index were determined, signs of a dental wear were thoroughly searched for. Main

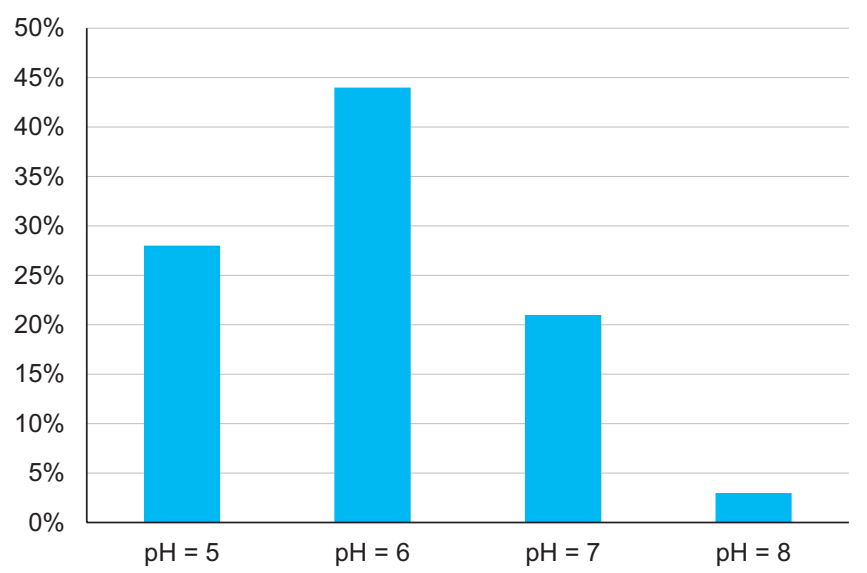

FIGURE 1. Values of salivary $\mathrm{pH}$ complaints were questioned, if mixed dentition was present, then the caries index was calculated for both deciduous and permanent teeth. The DMF-T (decayed-missedfilled teeth) and DMF-S (decayed-missed-filled surfaces) indexes were calculated for every situation.

The gingival index was measured to evaluate the gingival status, its color, consistency and bleeding tendency. Measurements were performed on six sites (tooth no. 16, $12,24,36,32,44)$, in five points for each site. ${ }^{2}$

Salivary $\mathrm{pH}$ was measured with the strip technique (LabStrip U11 Plus, 77 Elektronika, Hungary), directly inserted in the oral cavity. Intra-orally engaged strips were confronted with the guide strip, color changes were quantified in a possible range from 5 to 9 .

Tooth erosion was classified into four classes: 0 - absence of erosion; 1 - enamel surface is smooth, matt; 2 - chewing surface is full of tiny holes, the incisal edges is characterized by thinning, flattening of the rear corners of the teeth; 3 dentine exposure, discoloration and sensitivity.

\section{Statistical analysis}

All values were collected in Excel files. Statistical analysis was performed with the GraphPad InStat program (GraphPad, San Diego, CA, USA), the Mann-Whitney and Fisher tests were used.

\section{RESULTS}

From a total of 25 patients ( 11 girls and 14 boys) diagnosed with GERD, aged 5-17 years (mean age 11.2 \pm 5.7 years), 631 teeth were examined. Of these, 126 showed different types of caries lesions, the average value of the DMFT index being $19.81 \%$. Seventy-two percent of the patients presented no gingival reaction (gingival index 0 ), $24 \%$ had

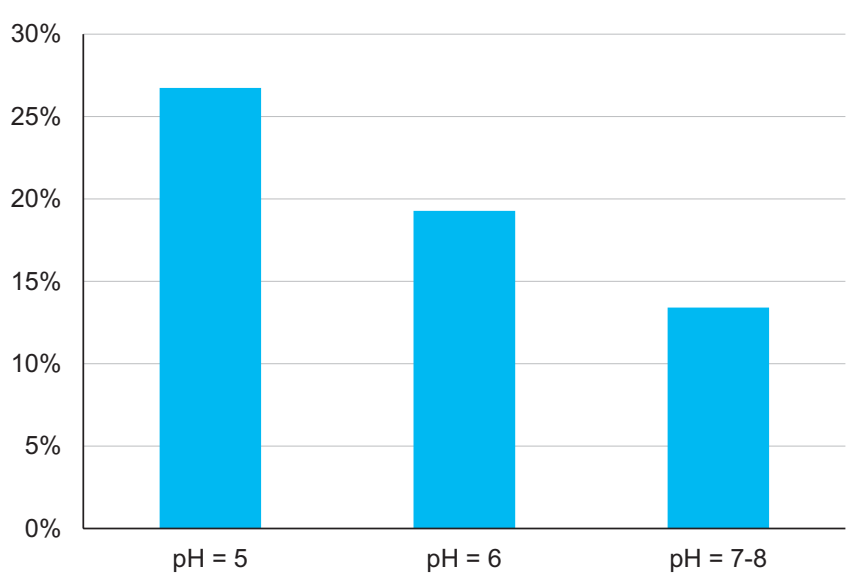

FIGURE 2. Correlation between $\mathrm{pH}$ values and the DMF-T index 
light gingival inflammation (gingival index 1) and in one case the index was 2 .

Regarding the value of salivary $\mathrm{pH}, 72 \%$ of the patients showed decreased oral pH (values 5 and 6), while $24 \%$ of cases had a normal $\mathrm{pH}$ value (between 7 and 8).

Analyzing the DMF-T index within groups of different $\mathrm{pH}$ values, teeth were more affected by caries at a $\mathrm{pH}$ value of $5(26.73 \%)$, at a $\mathrm{pH}$ value of 6 the DMF-T index was $19.28 \%$ and for $\mathrm{pH}=7-8$, the index was $13.41 \%$. The statistical comparison of the DMF-T indexes in different $\mathrm{pH}$ groups showed no statistical significance between the $\mathrm{pH}=5$ and $\mathrm{pH}=6$ groups $(\mathrm{p}=0.0692)$ and the $\mathrm{pH}=6$ and $\mathrm{pH}=7-8$ groups $(\mathrm{p}=0.1192)$, but statistical significance was found when the $\mathrm{pH}=5$ and $\mathrm{pH}=7-8$ groups were compared ( $p=0.0022)$. It can be said that there is a significant correlation between the $\mathrm{pH}$ value and caries: when $\mathrm{pH}$ values were acidic, dental lesions showed a significantly higher incidence rate compared to higher $\mathrm{pH}$ values. This may justify the severe effect of stomach acid on the teeth surface, underlying the hypothesis that oral lesions are more common in children suffering from GERD and the fact that there is a strong correlation between $\mathrm{pH}$ and tooth erosion.

\section{DISCUSSION}

Since the main symptom of GERD is correlated with the oral effect of gastric acid getting into the oral cavity, the salivary $\mathrm{pH}$ becomes acidic, which enables the formation of caries and tooth erosion.

In most cases, patients diagnosed with GERD show lower $\mathrm{pH}$ values and an increased frequency of tooth erosion and caries. ${ }^{3,4}$ This condition may worsen if bad oral hygiene is associated. 5,6

The detection of these oral lesions in GERD patients is a top priority; considering the link between lesion severity and acid reflux disease, an effective management of oral $\mathrm{pH}$ is needed. Most extra-esophageal lesions are located close to the upper esophageal sphincter due to the stomach acid. Thus, several structures can be damaged due to acid reflux, such as the pharynx, larynx, lungs, and the oral cavity, including the teeth. ${ }^{7}$

The absence or delay of GERD treatment will lead to other serious complications, such as chronic inflammations of the gastric and esophageal mucosa, bleeding and serious blood loss, ulcers and concomitant functional disorders, difficulty in swallowing and narrowing of the esophagus. The upper airways can also be affected; asthma or pneumonia can be induced. The most serious consequence of untreated GERD is esophageal cancer. ${ }^{8}$
A strong relationship between reflux disease and dental erosion has been found by several studies. Although the incidence of dental erosion is higher among adult patients (32.5\%) due to the longer contact with an acidic $\mathrm{pH}$, the same enamel lesions were found in children (17\%). ${ }^{9}$ In most studies, the GERD diagnosis was confirmed after endoscopic examination. Dahsan et al. found a $83.33 \%$ incidence of dental erosion in 24 GERD patients, most of them (41.66\%) showed mild type of enamel lesion. ${ }^{10}$ Salivary $\mathrm{pH}$ can be determined with other methods as well, we have chosen the strip method because it was less complicated, as we examined our subjects bedside. $24 \mathrm{~h}$ determination is also possible, so the fluctuation of salivary $\mathrm{pH}$ will not affect its value. O'Sullivan et al. found that only $16.98 \%$ of a group of 2-16 year-old children suffered from dental erosion, almost the same incidence we have found with the strip method determination. ${ }^{11}$ The method of establishing the GERD diagnosis is not so relevant either. After histological and symptoms-based diagnosis of GERD, the difference between dental erosion in GERD patients compared with subjects of a control group showed statistical significance; although these lesions were found on permanent teeth only, increased caries frequency was also found. ${ }^{12}$ Other studies showed a strong correlation between salivary $\mathrm{pH}$, dental erosion incidence and caries frequency as well. ${ }^{13,14}$

Besides GERD, many other factors can contribute to a low $\mathrm{pH}$ value; these are the so-called cariogenic factors such as bacteria, oral hygiene, diet, drugs. Carbohydrates from dental biofilm will develop harmful acids, which will reduce the $\mathrm{pH}$ to a critical level $(\mathrm{pH}$ 5.5), and this will trigger demineralization. If the enamel is exposed to a durable acidic attack, demineralization will occur, the enamel will lose its integrity, and enamel cavity will be formed. ${ }^{15}$ From a nutritional point of view, we can try to reduce the effect of acidic foods by reducing the intake of high quantities of carbohydrates: white bread, pasta, sugary drinks such as coffee, tea and juices. ${ }^{16}$ Demineralization and remineralization of the enamel depend on the salivary buffer capacity and volume. Demineralization occurs when the low $\mathrm{pH}$ buffering capacity of the saliva is not compensated, and the fluctuating $\mathrm{pH}$ leads to a short period of decreasing or increasing concentrations, leading to multiple periods of demineralization and remineralization. The buffer capacity of the saliva will act mostly on teeth that are in longer contact with the saliva, and the lower incisors are almost constantly humidified. The upper frontal region is in contact with saliva for a shorter time, and this might be the reason why certain studies declare the upper front teeth susceptible to dental ero- 
sion. ${ }^{17}$ Proper brushing technique and diet, lower intake of sugar-containing food and preventive local fluoride therapy can significantly reduce the incidence of caries and dental erosion. ${ }^{18}$

Although several studies have demonstrated that the extremely high acidity reduces bacterial growth, the mainly acidic oral environment in GERD may contribute to increased levels of acid-producing S. mutans bacteria, which will lead to increased caries frequency and other types of structural alterations of the enamel, such as dental erosion. ${ }^{19}$

\section{CONCLUSIONS}

This study was designed to prove that GERD patients with a low oral $\mathrm{pH}$ have a greater number of decayed teeth and there often they present signs of dental erosion. Salivary $\mathrm{pH}$ value is also affected by the reflux of gastric acid; our GERD subjects showed acidic, low salivary $\mathrm{pH}$ values. This will lead to the above mentioned dental lesions.

Patients suffering from reflux disease should be thoroughly followed, proper oral hygiene and nutritional advices must be given in each case in order to preserve the teeth and soft oral tissues intact. The dentist's job is to inform and advise these patients; the prevention can be achieved in several ways:

- constantly educating and motivating the patients to maintain good oral hygiene;

- use a soft-bristled toothbrush, dental floss;

- use of products containing fluoride: mouthwashes, gels and toothpaste with fluoride;

- proper diet, ignoring fried or fatty foods, chocolate, coffee, citrus juice, alcoholic beverages;

- the use of chewing gum, with saliva-stimulating effect;

- skipping meals at night;

- giving up smoking;

- more frequent visits to the dentist.

\section{REFERENCES}

1. Tulassay Zs. A belgyógyászat alapjai 1. Budapest: Medicina Könyvkiadó Zrt., 2010; p. 245-251.

2. Nyárasdy I, Bánóczy J. Preventív fogászat. Budapest: Medicina Könyvkiadó Zrt., 2009; p. 14-32.

3. Ersin NK, Onçağ O, Tümgör G, Aydoğdu S, Hilmioğlu S. Oral and dental manifestations of gastroesophageal reflux disease in children: a preliminary study. Pediatr Dent. 2006;28:279-284.

4. Di Fede O, Di Liberto C, Occhipinti G, et al. Oral manifestations in patients with gastroesophageal reflux disease: a single-center case-control study. J Oral Pathol Med. 2008;37:336-340.

5. Ranjitkar S, Smales RJ, Kaidonis JA. Oral manifestations of gastroesophageal reflux disease. J Gastroenterol Hepatol. 2012;27:21-27.

6. Kislig K, Wilder-Smith $\mathrm{CH}$, Bornstein MM, Lussi A, Seemann R. Halitosis and tongue coating in patients with erosive gastroesophageal reflux disease versus nonerosive gastresophageal reflux disease. Clin Oral Investig. 2013;17:159-165.

7. Farahmand F, Sabbaghian M, Ghodousi S, Seddighoraee N, Abbasi M. Gastroesophageal reflux disease and tooth erosion: a cross-sectional observational study. Gut Liver. 2013;7:278-281.

8. Ranjitkar S, Kaidonis JA, Roger J. Smales Gastroesophageal Reflux Disease and Tooth Erosion. International Journal of Dentistry. 2012;2012:479850.

9. Pace F, Pallotta S, Tonini M, Vakil N, Bianchi Porro G. Systematic review: gastroesophageal reflux disease and dental lesions. Aliment Pharmacol Ther. 2008;27:1179-1186.

10. Dahshan A, Patel H, Delaney J, Wuerth A, Thomas R, Tolia V. Gastroesophageal reflux disease and dental erosion in children. J Pediatr. 2002;140:474-478.

11. O'Sullivan EA, Curzon ME, Roberts GJ, Milla PJ, Stringer MD. Gastroesophageal reflux in children and its relationship to erosion of primary and permanent teeth. Eur J Oral Sci. 1998;106:765-769.

12. Linnett $V$, Seow WK, Connor F, et al. Oral health of children with gastroesophageal reflux disease: A controlled study. Aust Dent J. 2002;47:156-162.

13. Fábián G, Gábris K, Tarján I. Gyermekfogászat, Fogszabályozás és Állcsont-Ortopédia, I./4. Budapest: Semmelweis Kiadó, 2013.

14. Vályi P. Dentálhigiénikusok kézikönyve. Szeged: Szegedi Tudományegyetem, 2014/2015; p. 31-36.

15. Featherstone JDB. Dental caries: a dynamic disease process. Austr Dent J. 2008:53:286-291

16. Rosztóczky A, Wittmann T. Refluxbetegség - gyomorsav okozta bántalmak. Budapest: Gasztroenterológia, Springmed Kiadó KFT, 2006; p. 24-27.

17. de Almeida Pdel V, Grégio AM, Machado MA, de Lima AA, Azevedo LR. Saliva Composition and Functions: A Comprehensive Review. J Contemp Dent Pract. 2008;9:72-80.

18. Øgaard B, Alm AA, Larsson E, Adolfsson U. A prospective, randomized clinical study on effects of amine fluoride/stannous fluoride toothpaste/ mouth rinse on plaque, gingivitis and initial caries lesion development in orthodontic patients. Eur J Orthod. 2006;28:8-12.

19. Linnett V, Seow WK, Connor F, Shepherd R. Oral health of children with gastroesophageal reflux disease: A controlled study. Aust Dent J. 2002;47:156-162. 